\title{
Relasi Orang Tua dan Lembaga Pendidikan (Kajian atas Peran Paguyuban Kelas dalam Peningkatan Mutu Pembelajaran di SD Kemala Bhayangkari 5 Lamongan)
}

\author{
Rokim \\ Program Studi Pendidikan Agama Islam Universitas Islam Lamongan \\ E-mail: rokim060674@gmail.com
}

\begin{abstract}
Abstrak: Banyaknya orang tua yang memandang sebelah mata tentang kelas masyarakat yang ada di sebuah sekolah. Ini hanya sebatas mereka tahu bahwa masyarakat hanyalah alat penghimpun dana dan tidak berpengaruh bagi pendidikan anak. Nyatanya banyak di sekolah yang mempunyai struktur kemasyarakatan tetapi hanya untuk formalitas saja. Mereka akan pindah saat ada kunjungan. Oleh karena itu penulis mengangkat judul ini untuk mengetahui bagaimana sebenarnya peran masyarakat. Hasil penelitian dapat disimpulkan menjadi tiga hal, yaitu: (1) asosiasi kelas berperan sangat penting dalam prestasi belajar siswa. Peran masyarakat tersebut antara lain: kegiatan tahunan setahun dua kali, kegiatan sehari-hari dalam memantau pembelajaran di sekolah, kegiatan kelompok kelas dalam mengikuti kegiatan di sekolah dan kegiatan sosial. (2) Faktor pendukung terbentuknya perkumpulan kelas meliputi keterbukaan guru dalam menghadapi keluhan wali tentang pembelajaran anak, adanya motivasi dari komite sekolah, besarnya keinginan wali sendiri dan menghindari kesalahpahaman antara guru dan orang tua. (3) Bagaimana mengatasi faktor penghambat pergaulan dengan kegigihan guru dan ketua masyarakat memberikan motivasi dan dorongan akan pentingnya peran orang tua dalam meningkatkan prestasi belajar siswa.
\end{abstract}

Kata Kunci: Asosiasi Kelas, Prestasi Belajar PAI

Abstract: The number of parents looking one eye about the class of society that exist in a school. This is only to the extent that they know that the community is only a means of collecting funds and there is no effect for children's education. In fact many in schools that have the structure of the community but just for formality only. They will move when there is a visit. Therefore the author raised this title to know how the role of the actual community. The results can be concluded into three things, they are: (1)class associations play so important role in student achievement. The role of the community they are: annual activities a year twice, daily activities in monitoring learning in schools, class group activities in following activities at school and social activities. (2) Factor supporting the formation of class associations include teacher opennes in the face of the guardian's complaints about child's learning, there is motivation from school committe, the magnitude of the wishes of the guardians themselves and avoiding misunderstandings between teachers and parent. (3) How to overcome the factors inhibiting the association with the persistence of teachers and chairperson of the commounity provide motivation and encouragement of the importance of the role of parents in improving student achievement

Keywords: Class Association, Learning Achievement of Islamic Religious 


\section{Pendahuluan}

Pendidikan merupakan aspek yang sangat penting bagi kehidupan setiap warga negara. Pendidikan merupakan suatu usaha yang dilakunan secara sadar dan sengaja untuk mengubah tingkah laku manusia baik secara individu maupun kelompok untuk mendewasakan manusia melalui upaya pengajaran dan penelitian.

Pendidikan yang bermutu pada saat ini merupakan suatu kebutuhan yang sangat penting dalam kehidupan manusia. Maju tidaknya suatu bangsa sangat tergantung pada pendidikan bngsa tersebut. Jika pendidikan suatu bangsa dapat menghasilkan manusia yang berkualitas lahir batin, otomatis bangsa tersebut akan maju, damai dan tenteram. Sebaliknya jika pendidikan suatu bangsa mengalami stagnasi maka bangsa itu akan terbelakang disegala bidang. ${ }^{1}$

Dalam pendidikan tidak lepas dari aktivitas belajar dan setiap orang tua pasti menginginkan anak-anaknya berprestasi. Untuk mendapatakan prestasi belajar yang bagus selain guru dan pihak sekolah maka orang tua sangat berperan penting dalam membimbing dan mengarahan. Keluarga merupakan pusat pendidikan yang pertama dan utama karena keluarga memiliki pengaruh yang besar dalam membentuk kepribadian anak. Orang tua sebagai bagian dari keluarga akan sangat mempengaruhi tingkah laku anak. ${ }^{2}$ Oleh karena itu peran orang tua sangat penting untuk mendukung dalam meningkatkan prestasi belajar siswa, salah satunya sebagai fasilitator dan motivasi untuk anak-anaknya.

Dalam dunia pendidikan terdapat paguyuban yang dititik beratkan kepada peran serta orang tua siswa dengan mengatasnamakan organisasi paguyuban orang tua siswa khususnya pada jenjang pendidikan Sekolah Dasar. Paguyuban orang tua siswa dalam pendidikan merupakan suatu kelompok soasial atau organisasi yang anggota-anggotanya merupakan orang tua wali siswa yang dibentuk dengan tujuan untuk memajukan pendidikan dan menyumbangkan baik pikiran dan tenaganya dalam kemajuan pendidikan dilingkungan sekitar sekolah. ${ }^{3}$

Pendidikan yang berkualitas akan terwujud apabila orang tua turut berpartisipasi dalam menyelenggarakan pendidikan di sekolah. Orang tua tidak boleh begitu saja melepas tanggung jawab akan pendidikan anak kepada pihak sekolah. Orang tua harus berpartisipasi dalam pendidikan anak. Bentuk partisipasi orang tua terhadap sekolah bermacam-macam termasuk adanya paguyuban kelas. Kegiatan paguyuban ini membahas berbagai hal yang berhubungan dengan kebutuhan anak, laporan perkembangan belajar anak serta laporan perkembangan moral dan sopan santun anak selama di sekolah.

Namun dengan terbentuknya paguyuban kelas tidak jarang di struktur yang sudah ada hanya sebagai formalitas dan pada realitanya tidak berjalan. Karena banyak orang tua yang masih memandang sebelah mata terhadap paguyuban kelas tersebut. Banyak dari mereka menganggap paguyuban kelas hanya sebagai ajang untuk memungut dana saja dan pada hakikatnya terbentuknya oragnisasi paguyuban kelas itu sangat bagus dan mempunyai tujuan yang membangun.

\footnotetext{
${ }^{1}$ Ahmadi, Manajemen Kurikulum Pendidikan Kecakap Hidup (Yogyakarta: Pustaka Ifada, 2013), 1.

${ }^{2}$ Dwi Siswoyo Dkk, Ilmu Pendidikan (Yogyakarta: UNY Press, 2011), 140.

3 Irma Agustiani "Peran Paguyuban Kelas dalam Meningkatkan Kualitas Belajar Siswa di SD Al Kautsar Pasuruan”. Skripsi Universitas Negeri Malang.
} 
Menurut pengamatan peneliti oraganisasi paguyuban kelas sudah banyak terbentuk di beberapa lembaga terutama di Sekolah Dasar Bhayangkari 5 Lamongan. Lembaga ini merupakan lembaga yang sudah mendirikan oraganisasi paguyuban kelas sejak lama. ${ }^{4}$

Dengan latar belakang di atas, maka penelitiian ini terfokus pada pendeskripsian peran paguyuban kelas dalam meningkatkan prestasi belajar siswa di SD Bhayangkari 5 Lamongan dalam membentuk seorang yang kreatif, berakhlak mulia, dan berbudi tinggi. Berkenaan dengan permasalahan yang memnghambat berjalannya organisasi paguyuban kelas yang sangat kuat pengaruhnya pada pembelajaran. Maka dalam hal ini peneliti mengangkat penelitian skripsi dengan judul. "Peran Paguyuban Kelas Dalam Meningkatkan Prestasi Belajar Pendidikan Agama Islam Siswa Kelas II di SD Kemala Bhayangkari 5 Lamongan”.

\section{Paguyuban Kelas: Peran dan Fungsinya dalam Pendidikan}

Peran adalah suatu kompleks pengharapan manusia terhadap caranya individu harus bersikap dan berbuat dalam situasi tertentu yang berdasarkan status dan fungsi sosialnya. ${ }^{5}$

Pengertian peran lainnya yaitu peran merupakan aspek dinamis kedudukan, apabila seseorang melaksanakan hak dan kewajibannya sesuai dengan kedudukannya, maka ia menjalankan suatu peranan. ${ }^{6}$

Peran merupakan aspek dinamis dari kedudukan (status) yang dimiliki oleh seseorang, sedangkan status merupakan sekumpulan hak dan kewajiban yang dimiliki seseorang apabila seseorang melakukanhak-hak dan kewajiban-kewajiban sesuai dengan kedudukannya, maka ia menjalankan suatu fungsi.

Peran merupakan aspek yang dinamis dari kedudukan seseorang apabila seseorang melaksanakan hak-hak dan kewajibannya sesuai dengan kedudukannya maka orang yang bersangkutan menjalankan suatu peranan. ${ }^{7}$

Paguyuban kelas merupakan perkumpulan orang tua murid dalam suatau kelas yang bertujuan untuk membangun, menumbuhkan dan meningkatkan partisipasi, kepedulian dan tanggungjawab orang tua dengan memberikan saran dan masukan dalam meningkatkan hasil belajar. $^{8}$

Menurut Undang-Undang Nomor 20 Tahun 2003 tentang sistem pendidikan nasional, pasal 7 ayat 1 disebutkan bahwa orang tua berhak berperan serta dalam memilih satuan pendidikan dan memperoleh informasi tentang perkembangan pendidikan anaknya. ${ }^{9}$ Sedangkan menurut pasal 4 ayat 6 disebutkan bahwa pendidikan diselenggarakan dengan memperdayakan semua komponen masyarakat melalui peran serta dalam penyelenggaraan dan pengendalian mutu layanan pendidikan. ${ }^{10}$ Pasal 6 ayat 2 tertulis, setiap warga negara bertanggung jawab terhadap keberlangsungan penyelenggaraan pendidikan. Untuk memenuhi keikutsertaan masyarakat, telah diterbitkan Surat Keputusan Mentei Pendidikan Nasional No. 044/ U/ 2002 tanggal 2 April 2002 tentang dewan pendidikan dan Komite Sekolah yang

\footnotetext{
${ }^{4}$ Saidatul Hasanah, Wawancara, Lamongan, 21 Januari 2017.

${ }^{5}$ Abu Ahmadi, Widodo Supriyopno, Psikologi Belaja r( Jakarta: PT.Rineka Cipta., 1991).

${ }^{6}$ Soerjono Soekanto, Pengantar Sosiologi (Bandung, PT Renaya Rosdakarya, 2002), 243.

${ }^{7}$ Miftah Thoha, Pembinaan Organisasi (Proses Diagnosa dan Intervensi) (Jakarta: PT. Raja Grafindo Persada, 1997), 35.

${ }^{8}$ Soerjono Soekanto, Sosiologi Suatu Pengantar (Jakarta: Rajawali Pers , 2010), 119.

${ }^{9}$ Undang- Undang RI No. 20 Tahun 2003, Sistem Pendidikan Nasional (Bandung: Citra Umbara, 2003 ), 10.

${ }^{10}$ Ibid, 8.
} 
mengatur keikutsertaan masyarakat, dalam hal ini orang tua sebagai masyarakat pada tingkat sekolah. ${ }^{11}$

1. Bersama komite sekolah merencanakan, melaksanakan dan mengevaluasi program komite sekolah untuk mendukung peningkatan mutu sekolah dan prestasi belajar siswa.

2. Mendukung proses dan kegiatan belajar mengajar dikelas dalam wujud pemikiran, finansial dan tenaga.

3. Mediator antara orang tua siswa dengan wali kelas dan guru.

4. Sarana penggalian dan penggalangan dana dari alumni, masyarakat dan pelaku bisnis. ${ }^{12}$

\section{Peran Paguyuban Kelas Dalam Meningkatkan Prestasi Belajar PAI}

Dalam proses belajar mengajar pasti mempunyai tujuan tertentu yang membangun. Salah satunya adalah untuk memperoleh prestasi belajar yang baik. Untuk mendapatkan prestasi belajar yang baik tentunya banyak faktor yeng mempengaruhinya dari faktor internal maupun faktor eksternal. Sesuai dengan penjelasan diatas paguyuban kelas tidak kalah pentingnya dalam mendukung proses belajar agar mendapatkan hasil yang memuaskan.

Ada tiga kemungkinan keterlibatan orang tua terhadap pendidikan anak di sekolah, diantaranya: 1) Orientasi pada tugas; 2) Orientasi pada proses; 3) Orientasi pada perkembangan. $^{13}$

Berdasarkan pengamatan penulis bahwa terdapat beberapa kegiatan paguyuban yang dilaksanakan yaitu:

1. Peran serta paguyuban dalam kegiatan tahunan setiap semester.

Hal ini sesuai dengan pernyataan dari guru bahasa arab ibu Saidatul Hasanah bahwa, "wali murid selalu aktif hadir dalam kegiatan pertemuan rutin setiap semesternya terutama kelas II yang memang paguyubnnya sangat maju. Hal ini karena mereka sangat antusias dalam menyalurkan saran dan mengadakan konsultasi tentang proses pembelajarannya selama 1 semester. Paguyuban di SD Kemala Bhayangkari 5 Lamongan memang sudah terkoordinir sejak lama sehingga mereka aktif dalam kegiatan yang ada di sekolah". ${ }^{14}$

2. Keaktifan paguyuban dalam memantau pembelajaran anak di sekolah guna meningkatkan prestasi.

Hal ini sesuai dengan pernyataan dari ketua paguyuban ibu Farida Masydiana bahwa,"Kami sering hadir di sekolah ketika pembelajaran berlangsung, tetapi tidak semua mungkin bisa bergantian. Soalnya kami ingin memantau bagaimana perkembangan anak kami dalam pembelajaran dan ingin memastikan anak-anak kami bisa belajar dengan baik di sekolah. Selain itu kami juga ingin membantu guru saat pembelajaran berlangsung, biasanya kalau guru membutuhkan sesuatu untuk pembelajaran seperti harus membeli buku atau fotocopy untuk kebutuhan pembelajaran, maka dari kami bisa membantu membelikannya dengan dana paguyuban yang dikumpulkan. Hal ini kami lakukan agar anak-anak bisa belajar dengan baik dan mudah dalam menerima pelajaran". ${ }^{15}$

\footnotetext{
11 Syaiful Sagala, Manajemen Berbasis Sekolah Dan Masyarakat Strategi Memenagkan Persaingan Mutu (Jakarata: PT Nimas Multima, 2004), 165.

${ }_{12}$ Paguyuban Kelas (Definisi, Peran, Fungsi, Tugas dan Tanggung Jawab PAKES Sdn Sukasari 4 Tangerang)

Dalam http://Paguyuban-Kelas.blogspot.com/ diakses tanggal 05 Mei 2020.

${ }^{13}$ William Stainback dan Susan Stainback, Bagaimana Membantu Anak Berhasil di Sekolah, 5.

${ }^{14}$ Saidatul Hasanah, Wawancara, Lamongan 19 Mei 2020.

${ }^{15}$ Farida Masydiana, Wawancara, Lamongan, 08 Mei 2020.
} 
3. Keaktifan paguyuban dalam kegiatan di Sekolah.

Hal ini sesuai dengan pernyataan dari Siti Mar'atus Sholiah sebagai guru PAI bahwa, "anggota paguyuban kelas II memang sangat aktif ikut serta membantu kalau ada acara-acara di sekolah, seperti pas maulid nabi mengadakan acara lomba-lomba dan pentas yang menampilkan bakat-bakat siswa. Meraka selalu membantu dengan cara memberi motivasi anak-anaknya untuk mengikuti perlombaan dan ikut serta hadir menyaksikan. Selain itu ketika manasik haji semua wali muris sangat semanagat mengikuti kegiatan tersebut, selain mendampingi anaknya mereka juga ikut serta mempraktikkannya". ${ }^{16}$

5. Kegiatan sosial Paguyuban Kelas

Dalam paguyuban sesuai dengan pernyataan dari Farida Masydiana bahwa, "Selain mengadakan pertemuan rutinan setiap semesternya paguyuban juga mengadakan pertemuan ketika ada salah satu wali murid terkena musibah misalnya sakit, melahirkan atau muridnya yang sakit". ${ }^{17}$

a. Program Kerja Paguyuban Kelas

Progam kerja paguyuban kelas II sesuai dengan pendapat Farida Masydiana sebagai berikut.

1) Melakukan pertemuan orang tua/wali murid dengan wali kelas, waktu diselenggarakannya tidak terjadwal menyesuaikan kondisi.

2) Menginformasikan dan menjenguk siswa dan orang tua/wali murid yang mendapatkan musibah.

3) Menggalang kas kelas yang digunakan untuk tambahan kebutuhan siswa/kelas.

4) Mengakomodir kebutuhan maupun perlengkapan kelas.

5) Mengatur piket orang tua siswa yang harus hadir setiap hari di sekolah, untuk mendukung guru kelas dalam pelaksanaan proses pembelajaran.

6) Membantu orang tua siswa untuk memecahkan masalah yang dihadapi oleh seorang siswa di kelas yang bersangkutan.

7) Ikut serta membantu dalam kegiatan pembelajaran jika diperlukan. ${ }^{18}$

b. Fungsi Paguyuban Kelas

Menurut wali kelas II Tri Wuryati Ningsih, fungsi paguyuban orang tua di SD Kemala Bhayangkari 5 Lamongan sebagai berikut:

1) Paguyuban sebagai wadah yang dapat menjalin komunikasi anatar wali murid dengan guru di sekolah sehingga dapat terjalin kerjasama yang bagus.

2) Sebagai sarana untuk memecahkan masalah yang berkaitan tentang proses pembelajaran

3) Paguyuban membantu guru dalam memberikan motivasi dan arahan kepada siswa dalam meningkatkan prestasinya.

4) Adanya kegiatan paguyuban kelas memberikan kesempatan kepada orang tua untuk berperan aktif dalam proses pembelajaran.

5) Memberikan masukan kepada guru dan sekolah dalam meningkatkan prestasi siswa dan mendukung kualitas proses pembelajaran. ${ }^{19}$

\footnotetext{
${ }^{16}$ Ibid

${ }^{17}$ Ibid

${ }^{18}$ Farida Masydiana, Wawancara, Lamongan, 08 Mei 2020.

${ }^{19}$ Tri Wuryanti Ningsih, Wawancara, Lamongan, 05 Mei 2020.
} 


\section{Prestasi Belajar Siswa Pada Pelajaran PAI}

Menurut Siti Mar'atus Sholihah, bahwa sebagai guru PAI bahwa," Prestasi PAI anak tidak hanya diukur dengan nilai raport tetapi juga dengan bakat-bakat anak yang berkembang, contohnya dalam pelajaran PAI anak bisa menulis arab, membaca Al-Qur'an, bisa berpidato menggunakan bahasa arab, bisa mengerjakan sholat dan lain sebagainya. ${ }^{20}$

Selain itu beliau juga menjelaskan tentang prestasi belajar PAI siswa kelas II bawa, "Saya sebagai guru PAI siswa kelas II sangat bersyukur dengan adanya paguyuban kelas ini. Karena dengan dibentuknya paguyuban ini memudahkan guru dalam pembelajaran. Manfaat paguyuban ya bisa saya rasakan di pembelajaran PAI, karena prestasi mereka semakin meningkat dan itu bisa dilihat saat pembelajaran mereka lebih aktif dan peka dibandingkan ketika mereka masih kelas I. Prestasi mereka ini bisa dilihat dari akhlak, mereka bersikap sopan santun kepada guru atau orang yang lebih tua, saling menghargai dan toleransi. Selain itu yang paling membuat saya senang itu ketika PR yang saya kasih itu selalu mereka kerjakan di rumah, ketika saya tanya mereka juga aktif dalam menjawab ya walaupun jawabannya kurang tepat tetapi itu usahan dan mentalnya sudah cukup bagus". ${ }^{21}$

\section{Faktor-faktor Pendukung dan Penghambat Eksistensi Paguyuban Kelas}

\section{Faktor Pendukung}

Menurut Tri Wuryanti Ningsih, tentang faktor pendukung mengenai paguyuban kelas sebagai berikut," Menurut saya dalam melaksanakan peran paguyuban ini sebenarnya lebih mendomonasi faktor pendukungnya karena memanag dari wali murid itu sendiri sangat semangat katika dibentuknya kelompok paguyuban ini. Hal ini dikarenakan keinginan wali murid yang sangat tinggi dalam meningkatkan kepedulian terhadap pendidikan anaknya, supaya antara wali murid dan pihak sekolah tidak ada kesalah fahaman, wali murid sangat ingin meningkatkan prestasi anak-anaknya dengan adanya kelompok paguyuban, supaya silaturrahin antara wali murid dan pihak sekolah tetap terjalin dengan baik dan sebagai bahan evaluasi bersama".22

Sedangkan menurut ketua paguyuban Farida Masydiana tantang faktor yang mendukung terbentuknya paguyuban kelas sebagai berikut, "Kalau saya sendiri memang sudah tertarik dari awal untuk membentuk paguyuban ini, karena memang kebutuhan juga untuk kami para wali murid agar bisa selalu mengetahui perkembangan anak kami disekolah, paling tidak kita bisa langsung konsultasi dengan guru walinya anak-anak jika ada kesulitan dan itu memang sangat membantu. Paguyuban ini juga sangat bermanfaat bagi wali murid untuk saling membantu dan bertukar pikiran, contohnya kalau ada wali murid yang sait, lahiran dan lain sebagainya kita bisa menjenguk sekalian menyambung silaturrahmi", 23

\section{Faktor Penghambat}

Selain dengan adanya faktor-faktor pendukung di atas, dalam paguyuban kelas ini juga memiliki faktor-faktor penghambat. Ibu Siti Mar'atus Sholihah, S.Pd.I berpendapat bahwa," Disetiap kegiatan otomatis ada hambatannya, ya sama saja paguyuban juga ada

\footnotetext{
${ }^{20}$ Siti Mar'atus Sholihah, Wawancara, Lamongan 11 Mei 2020.

${ }^{21}$ Ibid.

22 Tri Wuryanti Ningsih, Wawancara, Lamongan, 05 Mei 2020

${ }^{23}$ Farida Masydiana, Wawancara, Lamongan, 08 Mei 2020.
} 
faktor penghambat, yaitu diantaranya 1) karena paguyuban kelas beranggota lebih dari 3 orang dan yang pastinya mereka punya kesibukan yang bermacam-macam, 2) Selain itu mereka juga mempunyai pola pikir yang berbeda dan 3) Rendahnya kepedulian orang tua sehingga susah untuk digerakkan." 24

Menurut ibu farida masydiana mengatakan tentang faktor penghambat paguyuban bahwa,"Sebenarnya kalau saya sendiri seneng mbak dengan dibentuknya paguyuban ini, tetapi lagi-lagi ada saja yang menghambat berjalannya paguyuban dan itu memang wajar. Hal itu dikarenakan kita sebagai orang tua punya kerjaan dan kesibukan sendiri dan tidak mungkin gampang untuk meluangkan waktunya karena memang kebutuhan. Namun meskipun begitu paguyuban kelas ini tetap berjalan dengan bagus hanya satu atau dua orang dari 13 anggota yang memang jarang aktif". ${ }^{25}$

Pendapat diatas juga diperkuat oleh Tri Wuryanti Ningsih, selaku guru wali kelas II bahwa," Saya sebagai wali kelas memang merasa adanya faktor penghambat tersebut dalam menggerakkan paguyuban ini, tetapi itu hal wajar kok mbak, dsamping mereka punya kesibukan yang berbeda, pemikiran yang berbeda juga kesadaran dari wali murid yang kurang. Selain itu paguyuban ini juga susah dalam membagi kepengurusan, dari dulu ketika masih kelas I sampai sekrang sudah naik ke kelas II ya tetep saya ketua dan pengurus yang lainnya juga masih tetap. Tetapi sejauh ini paguyuban kelas II ini berjalan dengan bagus dibanding kelas lainnya walaupun dengan adanya masalah-masalah tersebut mereka tetap aktif". ${ }^{26}$

\section{Cara Mengatasi Faktor Penghambat Peguyuban Kelas dalam Meningkatkan Prestasi PAI Kelas II di SD Kemala Bhayangkari 5 Lamongan.}

Menurut Tri Wuryati Ningsig, selaku guru wali kelas II, beliau berpendapat mengenai solusi yang bisa ditempuh untuk mengatasi faktor penghambat peguyuban kelas.

1. Dengan kesibukan wali murid yang berbeda maka saya sarankan kepada pengurus paguyuban untuk toleransi dan membagi tugasnya masing-masing agar paguyuban berjalan efektif.

2. Dengan pola pikir wali murid yang berbeda-beda maka saya selalu memberikan arahan kepada wali murid untuk menyadari bahwa peran serta orang tua sangat penting untuk meningkatkatkan prestasi siswa dan membangun silaturahim yang baik antar komite sekolah termasuk kepala sekolah, guru, staf sekolah dan wali murid.

3. Selain itu saya juga terus mengajak agar orang tua selalu aktif dan peduli akan kebutuhan anaknya dalam pembelajaran agar anak bisa nyaman dalam proses pembelajaran.

4. Dengan permasalahan sulitnya membentuk kepengurusan, maka agar paguyuban terus berjalan struktur kepengurusan di kelas II mau tidak mau masih tetap seperti pada masa kelas I"27

\section{Penutup}

Paguyuban kelas berperan penting terhadap peningkatan prestasi belajar siswa terutama dalam pelajaran PAI, beberapa peran paguyuban diantaranya: kegiatan tahunan setiap 1 semester 1 kali, kegiatan harian dalam memantau pembelajaran di sekolah, kegiatan

\footnotetext{
${ }^{24}$ Ibid

${ }^{25}$ Farida Masydiana, Wawancara, Lamongan, 08 Mei 2020

${ }^{26}$ Tri Wuryanti Ningsih, Wawancara, Lamongan, 05Mei 2020

${ }^{27}$ Ibid
} 
paguyuban mengikuti kegiatan sekolah dan kegiatan sosial. Faktor pendukung dibentuknya paguyuban antara lain keterbukaan guru dalam menghadapi keluhan wali murid tentang pembelajaran anaknya, adanya motivasi dari komite sekolah, keinginan yang kuat dari wali murid sendiri, menghindari terjadinya kesalah pahaman antara guru dan orang tua. Sedangkan faktor yang menghambat paguyuban kelas adalah kesibukan dan pola pikir antar orang tua yang berbeda, kurangnya kesadaran akan pentingnya pendidikan serta sulitnya kaderisasi.

Adapun cara dalam mengatasi faktor penghambat : (1) Wali kelas menyarankan kepada pengurus paguyuban untuk toleransi dan membagi tugasnya masing-masing agar paguyuban berjalan efektif. (2) Wali kelas selalu aktif menberikan motivasi dan arahan kepada wali murid akan pentingnya peran orang tua dalam meningkatkan prestasi anak.(3) Wali kelas selalu mengajak orang tua untuk peduli akan kebutuhan anak dalam pendidikan. (4) Wali kelas menyarankan agar paguyuban terus berjalan struktur kepengurusan di kelas II mau tidak mau masih tetap seperti pada masa kelas I.

\section{Daftar Rujukan}

Agustiani Irma. "Peran Paguyuban Kelas dalam Meningkatkan Kualitas Belajar Siswa di SD Al Kautsar Pasuruan”. Skripsi Universitas Negeri Malang.

Ahmadi, Manajemen Kurikulum Pendidikan Kecakap Hidup, Yogyakarta: Pustaka Ifada, 2013.

Djamarah, Saiful Bahri. Prestasi Belajar dan Kompetensi Guru, Surabaya: Usaha Nasional, 1994.

Paguyuban Kelas (Definisi, Peran, Fungsi, Tugas dan Tanggung Jawab PAKES Sdn Sukasari 4 Tangerang) Dalam http://Paguyuban-Kelas.blogspot.com/ diakses tanggal 05 Februari 2014.

Sagala, Syaiful. Manajemen Berbasis Sekolah Dan Masyarakat Strategi Memenagkan Persaingan Mutu, Jakarata: PT Nimas Multima, 2004.

Siswoyo, Dwi. Dkk, Ilmu Pendidikan, Yogyakarta: UNY Press, 2011.

Soekanto, Soerjono. Pengantar Sosiologi, Bandung, PT Renaya Rosdakarya, 2002.

, Sosiologi Suatu Pengantar, Jakarta: Rajawali Pers , 2010.

Stainback, William Stainback dan Susan. Bagaimana Membantu Anak Berhasil di Sekolah, Yogyakarta : Kanisius, 2001.

Supriyopno, Abu Ahmadi, Widodo. Psikologi Belajar, Jakarta: PT.Rineka Cipta, 1991.

Syah, Muhibbin. Psikologi Pendidikan, Bandung : Rosda Karya, 2002.

Thoha, Miftah. Pembinaan Organisasi (Proses Diagnosa dan Intervensi), Jakarta: PT. Raja Grafindo Persada, 1997.

Tu'u, Tulus. Peran Disiplin Pada Perilaku dan Prestasi Belajar Siswa, Bandung: Grasindo , 2004.

Undang- Undang RI No. 20 Tahun 2003, Sistem Pendidikan Nasional, Bandung: Citra Umbara, 2003.

Wuryanto, Saptono AD. "Inovasi Pemberdayaan Komite Sekolah (Reviw Tentang Pembentukan Paguyuban Kelas sebagai Langkah Inovatif untuk Eksistensi sebagai Sekolah Dengan Raktek yang baik atau Good Partice School pada SD Negeri 1 Panican UPT Dinas Pendidikan Kecamatan Kemangkon Kabupaten Purbaingga)", dalam sdnegeri1 panican.blogspot.co.id/2020-03-01-archive.html?m=1(14 Mei 2020) 